\title{
A STUDY ON PAGELLUS COUPEI DIEUZEIDE FROM THE NORTH-WEST AFRICAN REGION
}

\section{BADANIA NAD PAGELLUS COUPEI DIEUZEIDE Z REJONU PÓENOCNO-ZACHODNIEJ AFR YKI}

\author{
Institute for Exploitation of Sea Resources \\ and Institute of Ichthyology \\ This work presents investigations of morphological \\ characters, age composition, rate of growth, reprodu- \\ ction and food of Pagellus coupei Dieuzeide. It had \\ been ascertained that, in North - West African re- \\ gion, this species forms at least three stocks, i.e. in \\ Rio de Oro, Dakar and Tacoradi region. Worked out \\ is the key to species of Pagellus for region discussed.
}

\section{INTRODUCTION}

The North-West African waters present considerably good conditions for production of plankton due to upwelling which appears here on wide regions. The water is rich in food for numerous species of pelagic and bottom fish.

Considerable part of catches here represent the family of sea-bream (Sparidae). With an increase of fishing intensity, the catches of fish belonging to this family, was growing from 83.7 thousands of tons in 1957 to 151.9 thousands of tons in 1966. The yield per unit of fishing effort had gradually been decreasing from $182 \mathrm{~kg} / \mathrm{h}$ per haul in 1957 to $41 \mathrm{~kg} / \mathrm{h}$ per haul in 1966 (F A O) 1968).

Participation of breams in Polish fishery for period 1964-1968 tended towards decrease. Polish catches of these fishes expressed in absolute values for the period, proved the decrease from 4.6 thousands of tons to 1.5 thousand of tons.

Considering such circumstances, the more detailed investigations on Sparidae family which still is hardly known, may have great meaning for rational economy of their resources.

The present study relate to biology of one from most frequently encountered in this region representant of Sparidae family, i.e. Pagellus coupei Dieuzeide. 


\section{MATERIAL AND METHOD}

The work is based on materials collected between 5. December 1968 to 27. February 1970 from region extending from Dakar to Rio de Oro at North-West African coast. Some fish were taken in port from catches of several trawlers type B-23 (Table 1).

T a b l e 1

Number of examined fishes and analysis performed

\begin{tabular}{|l|c|}
\hline \multicolumn{1}{|c|}{ Analysis } & Number of fishes \\
\hline Measurements of : & \\
Length & 295 \\
Weight & 1950 \\
Diameter of eye & 63 \\
Preorbital width & 62 \\
Examination of stomach content & 71 \\
Estimation of stomach filling & 804 \\
Taking otoliths for determination of age & 930 \\
Taking gonads for determination of fecundity & 10 \\
Estimation of gonads maturity & 1031 \\
\hline
\end{tabular}

The length of head, diameter of eye and the width of preorbitals were measured with accuracy of $1 \mathrm{~mm}$ (diagram of measurements Lé - Tr o $\mathrm{ng}$ $\mathrm{Ph} \hat{\mathrm{a}} \mathrm{n}$ and K $\mathrm{Km} \mathrm{p}$ ow s ki, 1972). Diameter of eye and the preorbital width have been expressed in per cent of the head length. Total length was measured with an accuracy of $1 \mathrm{~cm}$, i.e. length class of $20 \mathrm{~cm}$ comprised the fish between 20.0 to $20.9 \mathrm{~cm}$. The age was determined according to otoliths and verified according to scales. The back readings of the growth rate were effected by application of microscope with micrometer. The states of gonads were noted according to Maier's eight-degree scale. The food was examined by weighing method and by counting the organisms present in alimentary canal.

\section{MOR PHOLOGICAL CHARACTERS}

The body of $\mathrm{P}$. coupei is elongated and the eye is considerably small. Fish is coloured in pink with several small blue spots. The rays of dorsal fin are short; none of them is developed more strongly. Number of scales on lateral line oscillates from 55 to 58. Dorsal fin (D) XII-10, anal fin (A) JIII-10. Number of rings is constant and amounts to 24 .

Pagellus coupei is closely related to $\underline{\mathrm{P} \text {. erythrinus }}(\mathrm{L})$, but the first one has smaller height of body.

The investigations on relative size of eye diameter and on the preorbital width proved that these values are changing according to region of fish living (Table 2), and are different for region north of Dakar than in Rio de Oro region. Statistic analysis indicate that the differences are significant and are 
not resulting from errors of measurement. Investigations performed by $\mathrm{Sk}$ ornjak ov (1963) in Takoradi region $\left(4^{\circ} \mathrm{OO} \mathrm{N}\right)$ and at Dakar, on ratio between diameter of eye and length of head of this species, proved that this ratio amounted $31.711 \%$ and $29.32 \%$ respectively. It is apparent that diameter of eye of $\mathrm{P}$. coupei is reducing northwards, viz. :
Takoradi
$-31.71$
Dakar
$-30.48$
Rio de Oro
$-28.24$

Diameter of eye and preorbital width expressed in per-cent to head length of $P$. coupei

\begin{tabular}{|c|c|c|}
\hline $\begin{array}{c}\text { Morphological } \\
\text { characteristic }\end{array}$ & $\begin{array}{c}\text { Region Rio de Oro } \\
23^{\circ}-24^{\circ} \mathrm{N}\end{array}$ & $\begin{array}{c}\text { Region Dakar } \\
16^{\circ} \mathrm{N}\end{array}$ \\
\hline Diameter of eye & $24.3-31.9$ & $27.3-31.9$ \\
& 28.24 & 30.48 \\
$\mathrm{range}$ & 2.3598 & 1.4916 \\
$\mathrm{x}$ & 23 & 40 \\
Preorbital width & $15.8-21.0$ & $15.7-20.4$ \\
\hline range & 18.24 & 17.44 \\
$\bar{x}$ & 23 & 40 \\
$\mathrm{n}$ & & \\
\hline
\end{tabular}

Due consideration must be given to fact that investigations of Skornjakov were based on fish length of $13-20 \mathrm{~cm}$, while the present investigations - on fish length of $18-31 \mathrm{~cm}$.

Basing on keys for fish determination processed previously for discussed region (P e r ri e r, 1924; F o w l e r, 1936; Skorn j a k o v, 1963b) and supplementing this with observations of Die u z e id e (1960), M a ur i n (1968) and our data, the below given key had been worked out.

Key to species of Pagellus for the North-West African shelf:

1. Scales on occipital region are reaching to middle of eye . . . . . 2

- Scales on occipital region are reaching utmost the back edge of eye . 4

2. Dark spot at base of pectoral fin, 68-72 scales on 1.1. ............ Pagellus acarne (Risso, 1826).

- No dark spot at base of pectoral fin, 55-62 scales on 1.1. . . . . .

3. Straight frontal, 61-62 scales on 1.1., 9 soft rays in anal fin ... .............. Pagellus erythrinus ${ }^{\circ}$ (L., 1758).

- Convex frontal, 55-58 scales on 1.1. , body height smaller than at previous species, 10 soft rays in anal fin . . . . . . . . . . .......... Pagellus coupei Dieuzeide, 1960 .

4. 11-12 soft rays in anal fin, 6 or 7 rows of scales on cheek . . . .

- Max. 10 soft rays in anai fin, 5 rows of scales on cheek, 7 vertica] streaks on back and sides of body . . . . . . . . . . . . 
5. Dark spot at begining of 1.1., 7 rows of cheek scales . . . . . . ........ Pagellus centrodontus (de la Roche, 1809).

- No dark spot at begining of 1.1., 6 rows of cheek scales . . . . . . ......... Pagellus bogaraveo (Brünnich, 1764).

\section{LENGTH, AGE AND RATE OF GROWTH}

$\mathrm{L}$ e $\mathrm{ng} \mathrm{t} \mathrm{h}$

Length of $P$. coupei caught oscillated within $7-35 \mathrm{~cm}$. Average length

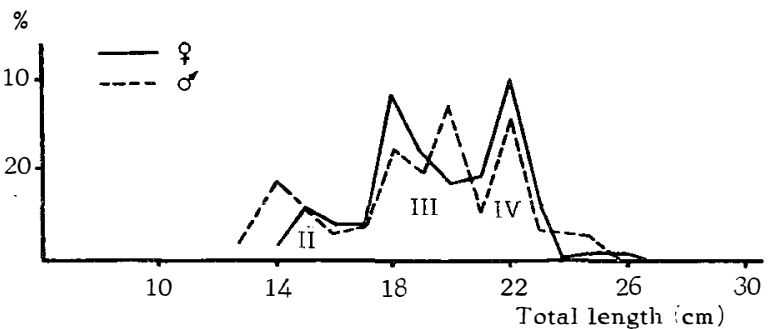

Fig.1. Length distributions curves of P. coupei in February 1970 amounted to $19.3 \mathrm{~cm}$. No distinct differences in length of males and females were noted (Fig. 1). An average length of $P$. coupei can be related to depth of fishing, e.g. during the period of 23 XII 1.969 to 1911970 on depths below $50 \mathrm{~m}$, average length of fish for this species amounted to $10.0 \mathrm{~cm}$; on depths $50-100 \mathrm{~m}-17,7 \mathrm{~cm}$

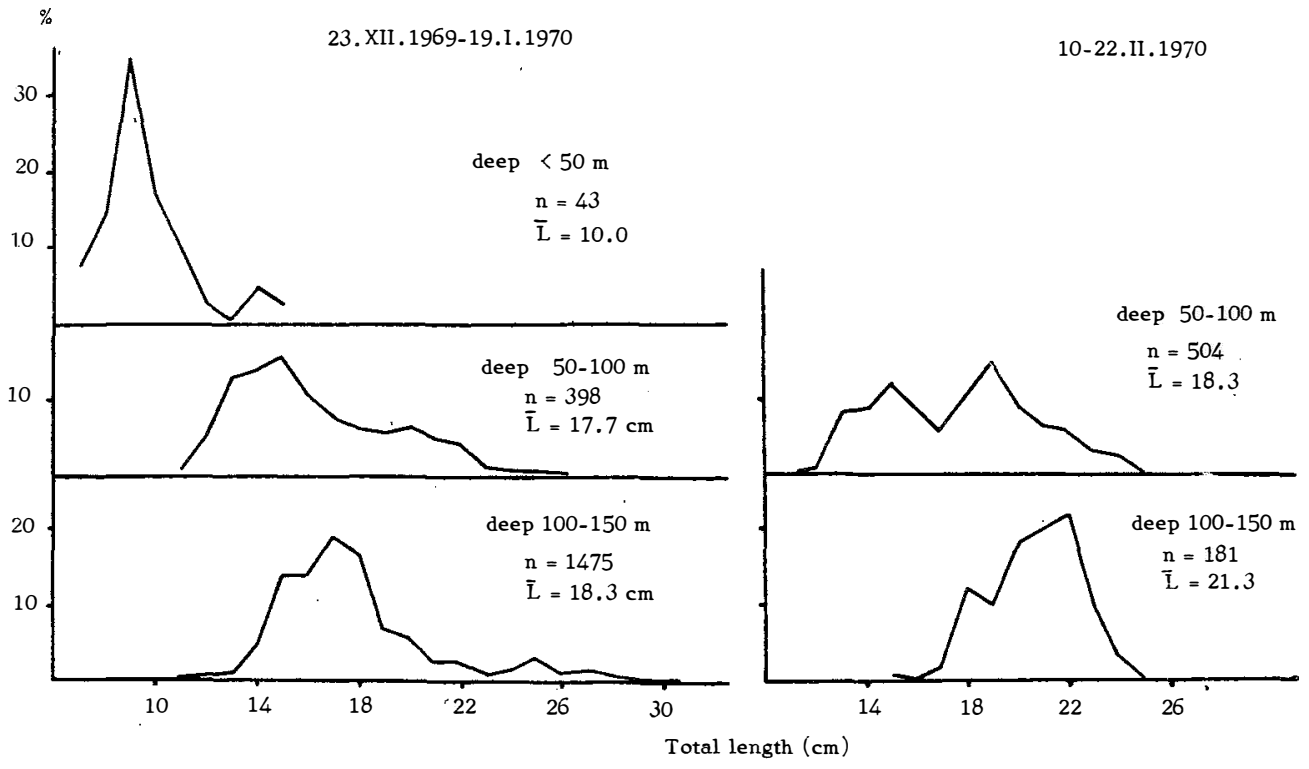

Fig.2. Length oscillation of $\mathrm{P}$. coupei in relation to depth of catch

and on depth 100-150 m - $18.3 \mathrm{~cm}$ (Fig.2). It is thus apparent that depending on its size, $\mathrm{P}$. coupei occupies various ecological niches. The fry is living 
in more shallow coastal waters and is changing the place for deeper waters in relation to its growth (of course is not exceeding the waters of optimal deep for this species). It may be assumed that, reproduction of $P$. coupei is taking place in coastal region.

The length distribution curves for $\mathrm{P}$. canariensis from February 1970 catches has some peaks in length-class of $14-15 ; 18-19$ and $22 \mathrm{~cm}$ (Fig.1). In determination of age by otoliths, it is evident that these peaks correspond to age-groups II, III and IV respectively.

The rings formation on otoliths

Owing to non-sufficient material, the method for determination of rings formation period applied to species $\mathrm{P}$. acarne ( $\mathrm{L}$ ê $-\operatorname{Tr} \circ \mathrm{ng} \mathrm{P} h \hat{a} \hat{n}$ and K $\circ \mathrm{m}$ p ow s k i, 1972), could not be applied in this case. Calculated, was the per cent of specimen with ring forming on otoliths edge from catches of various months and assumed that rings formation prevails on time of the highest percentage. The results (Table 3) proved that majority of fishes had already new formed ring on otolith edges in May. It is apparent that the period of rings formation lasts considerably long time.

$$
\text { T a b l e } 3
$$

Period of rings formation on otoliths of P. coupei Dieuzeide in 1970

\begin{tabular}{|l|c|c|c|}
\hline Month & $\begin{array}{c}\text { Per cent of fish with } \\
\text { ring on otolith edge }\end{array}$ & $\begin{array}{c}\text { Per cent of fish with- } \\
\text { out ring on otolith } \\
\text { edge }\end{array}$ & $\mathrm{n}$ \\
\hline January & 59.0 & 41.0 & 448 \\
February & 71.5 & 28.5 & 115 \\
May & 94.6 & 5.4 & 203 \\
\hline
\end{tabular}

Age and mortality $\ln N$

The stock of $\underline{P}$. coupei from re- 5 gion northward of Dakar was composed of 9 age-groups. The percentage of age-groups from 0 to VIII was: 4.7 ( 0 and $I)$; 35.3 ; $45.3 ; 10.7 ; 2.8 ; 0.5 ; 0.4$ and 2 0.2 respectively. This clearly indicates that the catches are 1 based mainly on fishes belonging to II, III and IV age group. Total mortality rate estimated on basis of the above given age composition (Fig.3), amounted for northward region of Dakar in 1970 to value 1.58 ; total mortality taken by means of Ricke r's (1958) tables amounted to 0.7941 .

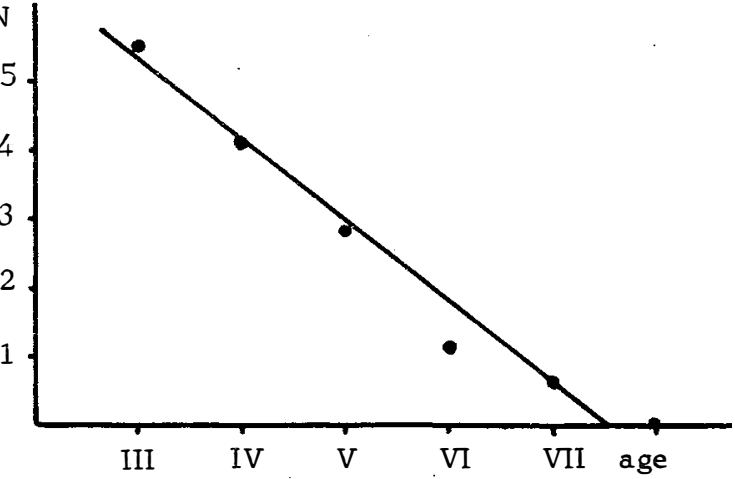

Fig.3. Estimation of total mortality rate of $\mathrm{P}$. coupei based upon age composition of Dakar stock in 1970 
Rate of growth

From measurements of otolith radius of 316 fishes $8-31 \mathrm{~cm}$ in length it appears that the relation between the longer otolith radius and total length of fish is nearly directly proportional and is expressed by an equation: $R=3.3014+2.9995 \mathrm{~L}$. The straight obtained from equation crosses the arrangement of coordinates nearly at zero point (Fig.4).

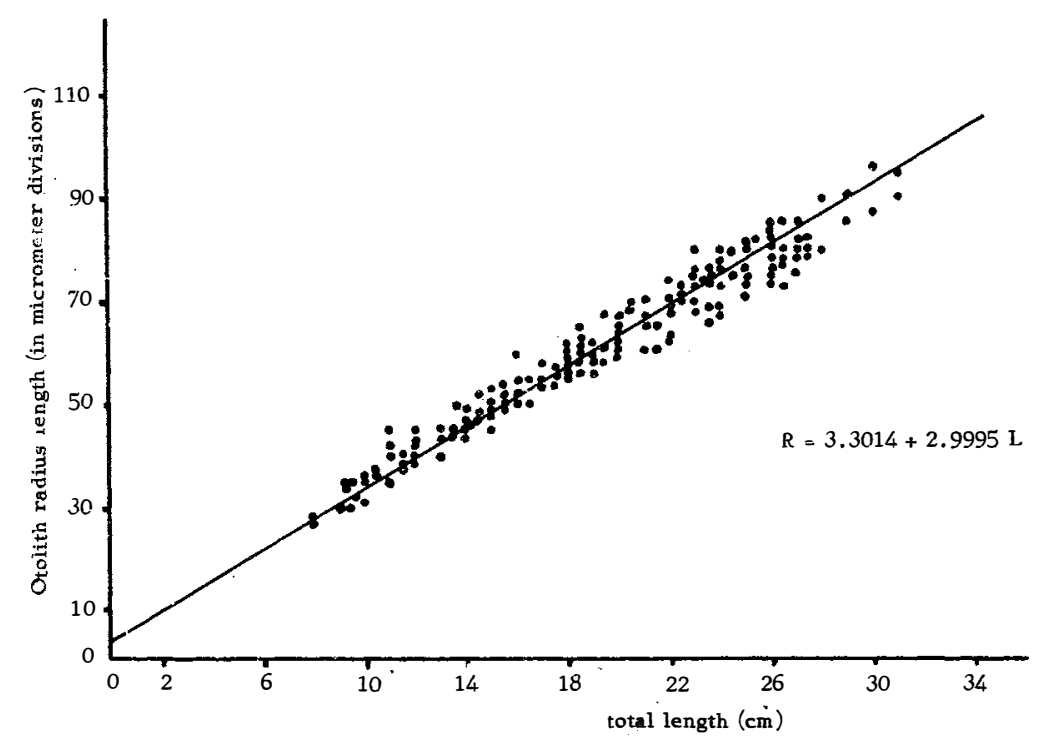

Fig.4. Corelation between total length and length of otolith radius

For these reasons, no corrections were applied at the back reading of growth rate, but applied the method based on direct proportionals. The obtained results are shown on Fig.5. Approximative results were also obtained from direct measurements of length in particular age-groups. The rate of growth for specimen living in Rio de Oro region was higher than of those living in region north of Dakar. The statistical analysis shows that the difference is significant. S k o r n a k ov (1969) ascertained that the rate of growth of $\underline{P}$. coupei in Takoradi region was lower than for Dakar region. Such data permits to conclude that $\underline{P}$. coupei forms three various stocks in region of Takoradi, Dakar and Rio de Oro. The rate of growth for the specimen of these stocks increase northwards (from Takoradi towards Rio de Oro). Such conclusion is in conformity with the results of the studies of the morphological features. Similar tendency for formation of local stocks, differing, among others, in morphological features, condition and rate of growth, proved P.acarne (L ê - Trong Phân and Kom pow s ki, 1972). Inboth cases, this may be assigned to small activity wi.ich favours an isolation of fishes which belong to Pagellus genus. In contrary to pelagicfish (mackerel, sardinella) these fishes move periodically across the shelf, but not along the shelf. 


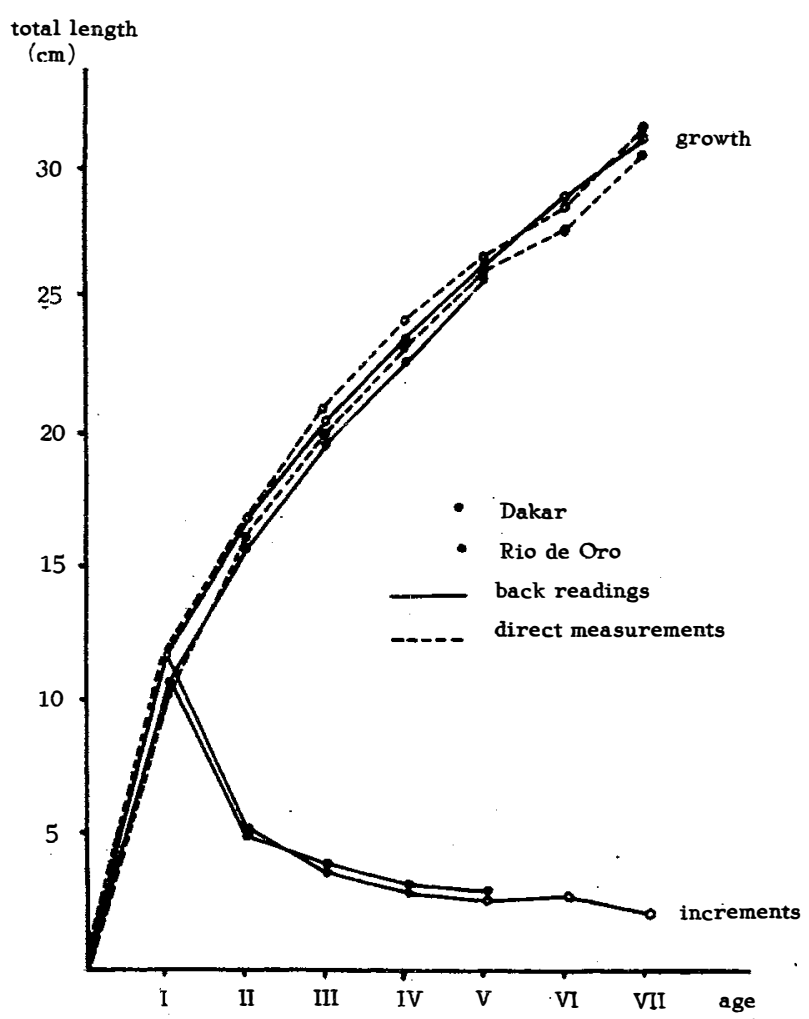

Fig.5. Rate of growth of P. coupei from various region

By measurements of 200 fishes the correlation between length and weight was determined and it may be expressed by formula: $\mathrm{W}=0.0139 \mathrm{~L} 2.991$. Applying this equation, the fish weight in age-groups I to VII was calculated and it amounts to: $22,63,116,167,239,325$ and $402 \mathrm{~g}$ respectively. It is apparent that the annual weight increments are increasing up to the sixth year of life.

According to results of back readings, the rate of growth for $P$. coupei was expressed as an equation of $v$. Bertalanffy. The parameters of such equation for $P$. coupei from Dakar region amount to: $L_{\infty}=39.37 \mathrm{~cm} ; \mathrm{K}=$ $=0.18 ; \mathrm{t}_{\mathrm{o}}=-0.81$ year, while from Rio de Oro region, $\mathrm{L}_{\infty}=40.17 \mathrm{~cm}$; $\mathrm{K}=0.19 ; \mathrm{t}_{\mathrm{o}}=-0.63$ year.

\section{REPRODUCTION}

The phenomenon of hermaphroditism exists at $\mathrm{P}$. coupei like of $\mathrm{P}$. acarne (L ê - Trong Phân and Kom pow sk $\bar{i}, \frac{1972)}{1}$. In contrary to P. acarne, the hermaphroditism here is of protogynia type, i.e. the youn specimen acts as female and thenafter transforms to male. Spawning of $P$. coupei is portional and lasts from May to September. In his investigations. 


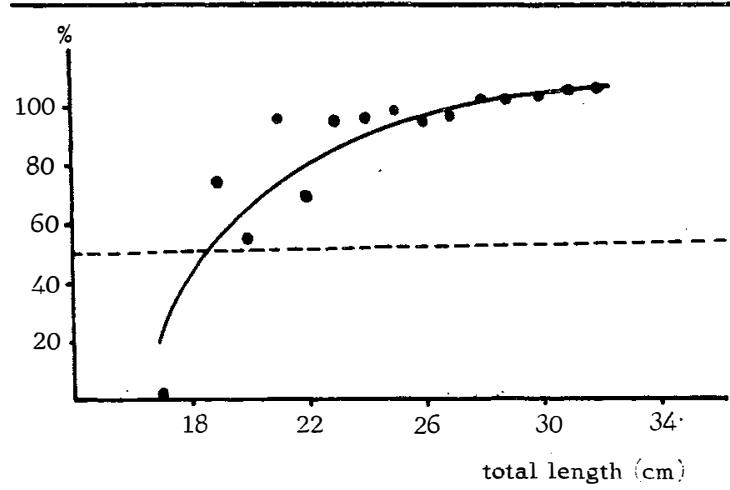

Fig.6. Length composition of spawning population of $\mathrm{P}$. coupei

Skornjak ov (1963a) ascertained that spawning of P. coupei in Takoradi region is taking place from November to March, i.e. some months earlier than in Dakar - Rio de Oro region. This data and the observations presented in other works 'W o źn i a k, 1965; L ê - Trong - P h ân and $\mathrm{K} \circ \mathrm{m} \mathrm{p} \circ \mathrm{w} \mathrm{s} \mathrm{ki}$, 1972) indicate that the fishes from regions nearer to Equator spawn earlier than those from regions of higher geographical latitudes.

The gonads start maturing earlier at males. The percentage of females in catches of various months oscillated from 40.7 to 55 , giving the mean value of 48.3 . The percentage of males oscillated from 45.0 to 59.3 , giving the mean value 51.7 (Table 4 ).

T a ble 4

Number ratio of females to males of $P$. coupei

\begin{tabular}{|l|c|c|c|}
\hline \multirow{2}{*}{ Month } & \multicolumn{2}{|c|}{ Sex $\%$} & \multirow{2}{*}{$\mathrm{n}$} \\
\cline { 2 - 4 } & o & $\sigma$ & \\
\hline V. 1969 & 55.0 & 45.0 & 198 \\
IX. 1969 & 40.7 & 59.3 & 209 \\
I. 1970 & 49.0 & 51.0 & 480 \\
II. 1970 & 46.5 & 53.5 & 140 \\
\hline T o t a 1 & 48.3 & 51.7 & 1027 \\
\hline
\end{tabular}

Generally the number of males was lower than that of females. The gonads of matured females attain the weight of 4 to $27 \mathrm{~g}$. The absolute fecundity oscillated between 60.2-406.8 thousands of eggs. The specimen with ripening sex products were observed in region from $21^{\circ} 00^{\prime} \mathrm{N}$ to $24^{\circ} 00 \mathrm{~N}$ during the spawning period. The investigation results of $\mathrm{S} \mathrm{k}$ or n j a k o v (1963a) indicate that the ripening specimen were also appearing in region of Takoradi and $\mathrm{Da}$ kar. It is apparent that the fishes spawn at the place of their living, but for reproduction move to more shallow waters where the fry encounters later on better feeding conditions. It may be seenfrom drawing 6 that among the fish of $19-25 \mathrm{~cm}$ in length, percentage of specimen spawning amounts to above 50 . All fishes of lengths above $25 \mathrm{~cm}$ were already matured. It may be said that the first spawning of this species is taking place at age $1+$. 


\section{FEEDING}

Percentage of particular groups of food was changing in relation to season of year. In May, fishes were feeding mainly on Amphioxus, which presented at that time $63.9 \%$ of stomach content by weight, $84.1 \%$ of number of eaten organisms and was appearing in $90 \%$ of examined stomachs. On second place were Pisces. Polychaeta and Decapoda (Fig.7).

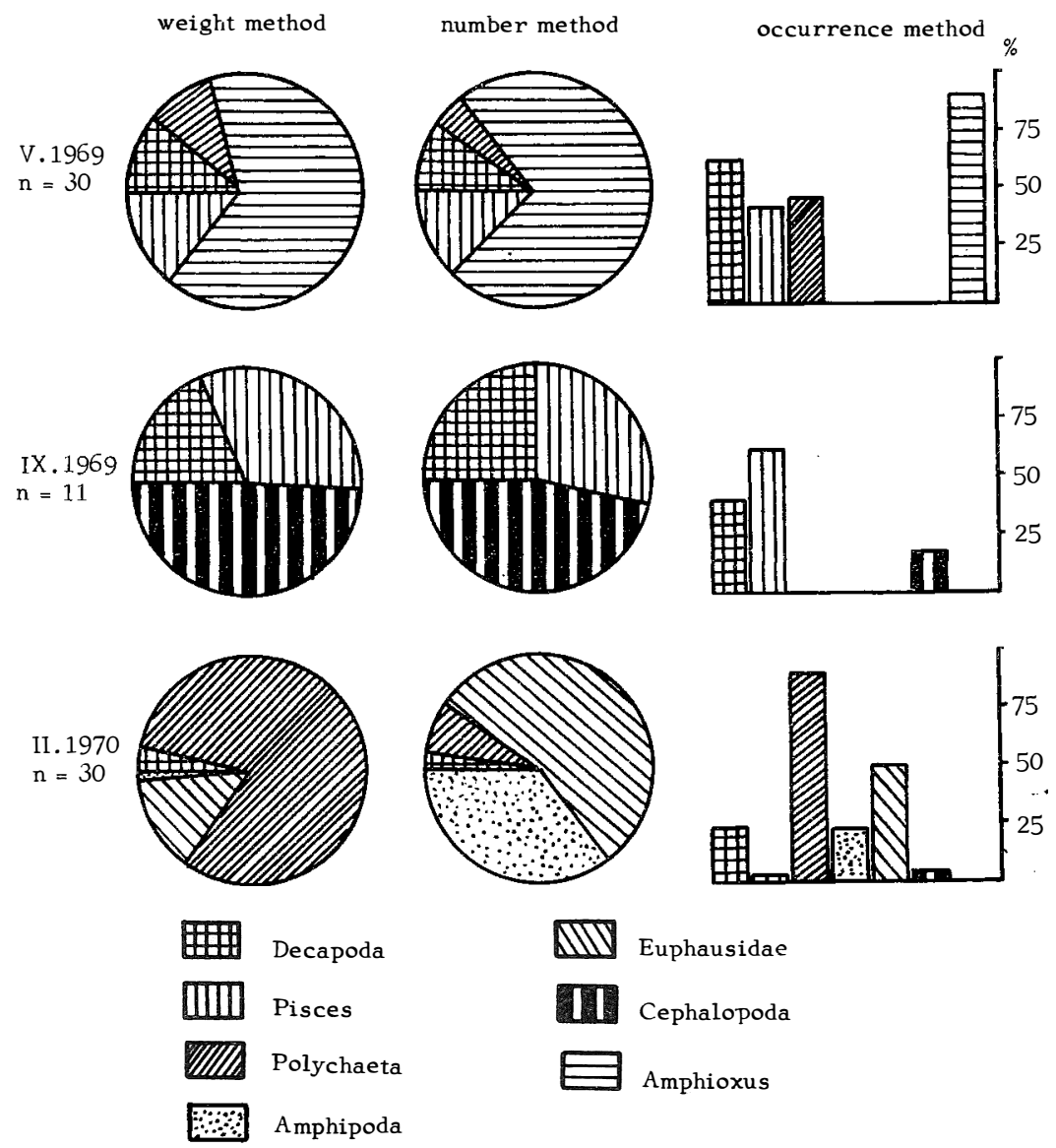

Fig.7. Composition of food of P. coupei for various seasons of year

Different composition of food was in September. No Amphioxus and Polychaeta was found, but it appeared a new component - Cephalopoda. This group is taking considerable part in food and it presented at that time $48.5 \%$ of food weight. Appearing also beyond Cephalopoda were: Pisces - $32.5 \%$ and Decapoda - 19.0\%.

Cephalopoda and Pisces were not present in food in February; appearing instead were Euphausidae, Amphipoda and Ophiuroidea. Main food of this month comprised Euphausidae and Polychaeta, which presented respectively 12.4 and $82.4 \%$ of stomach content by weight and 53.4 and $5.8 \%$ of number of eaten organisms. 
It is apparent that Decapoda, Cephalopoda, Pisces, Amphioxus and Polychaeta are the essential components of food, but each of them dominates in different annual season.

Analysis of degree to which alimentary tracts are filled, lead to coriclusion that intensive feeding of fish prevailed in summer period and less intense for winter period. Any internal changes of physiological condition during spawning period, has no distinct influence of feeding of $\underline{P}$. coupei. Intensive feeding is also taking place during spawning period, what is supported by fact that some specimen with ripening sex products were found with strongly filled alimentary tracts.

\section{CATCHES}

The greatest abundance of the $P$. coupei may be found in regions of $\mathrm{Rio}$ de Oro, Dakar, of Guinea and Sierra Leone. Yield of catches of this species during 23. XII.1969-10.II.1970 on depths 50-180 m (in average 107-116 m) amounted to $9.9-41.7 \mathrm{~kg} / \mathrm{h}$ of haul; i.e. 0.4-1.6\% of total catches. Such relatively small yield may be explained by fact that this species is living primarily on smaller depths within the territorial waters which are not accessible for Polish fishing fleet. This is supported by data of $M$ a s s u t i (1967), who noted that P. coupei forms the large concentrations in coastal region of Guinea and Sierra Leone at depth of 40-50 m. Average yield from here amounted to about $60 \mathrm{~kg} / \mathrm{h}$ per haul, what presented about $20 \%$ of total catches. In one haul at Dakar region on depth $46-48 \mathrm{~m}$, yield of $\underline{\mathrm{P}}$. coupei amounted even to $210 \mathrm{~kg} / \mathrm{h}$ per haul.

\section{REFERENCES}

Die uz e ide R., 1960: A propos d'un Pagellus nouveau pour la Mediterranée: P. coupei n. sp. Bull. Stat. Aquic. Pêches Castiglione, 2.

F A O, 1968: Fisheries Reports. 56, supl. 1.

F o w l e r H.W., 1936: The marine fishes of West Africa. Bull. of Amer. Mus. of Nat. Hist., 70, 2 .

L ê - trong P hấn, K o m p o w s ki A., 1972: The bronze bream Pagellus acarne 'Risso) from North-West African region. Acta Ichthyol. et Piscatoria 2 .

M a s u ti M., 1967: Los fondos de pesca en la plataforma continental de Marruecos, Sáhara español, Mauritania, Senegal, República de Guinea, Ensenada de Biáfra y archipielago de Cabo Verde. Trabajos del Instituto Español de Oceanografia, 34.

Ma u rin C., 1968: Ecologie ichthyologique des fonds chalutables atlantiques de la Baie Ibero-Marocaine a la Mauritanie et de la Mediterranée occidentale. Revue Travaux Inst. Pêch. Marit. 32, 1. 
Nikolski G.W., 1965: Teoria dinamiki stada ryb kak biologičeskaja osnova racionalnoj eksploatacji i proizvodstva rybnych resursov. Izd. "Nauka".

P e r rie r R., 1924: La faune de la France, 10.

R i ck e r W.E., 1958: Handbook of computations for biological statistics of fish population. Bull. Fish Res. Board., Canada, 119.

S k o r n jak ov V.I., 1963a: Morfo-biologičeskaja charakteristika Pagellus canariensis Val. zapadnogo pobereža Afriki. Trudy AtlantNIRO,10.

S k ornjak ov V.I., 1963b: Ryby semejstva sparovych (Sparidae) i perspektivy ich promysla u zapadnogo pobereža Afriki. Trudy AtlantNIRO, 10 .

S k o r n j a k o v V.I., 1969: O lokalnosti stad Pagellus canariensis Val. Trudy Kaliningr. Techn. Inst. Rybn. Prom. i Choz., 24.

W o ź n i a k St., 1965: Some observations of spawning fish over the shelf of the east tropical Atlantic. I C E S, Annales Biologiques, 20.

\title{
BADANIA NAD PAGELLUS COUPEI DIEUZEIDE Z REJONU PÓ£NOCNO-ZACHODNIEJ AFRYKI
}

\author{
Streszczenie
}

Pagellus coupei Dieuzeide, gatunek o słabo dotychczas poznanej biologii, należy do rodziny Sparidae, która odgrywa ważną rolę w rybołówstwie rejonu północno-zachodniej Afryki.

Materiały zebrano w okresie XII 1968-III 1970. Pochodziły one z połowów polskich trawlerów na szelfie północno-zachodniej Afryki, między równoleżnikami $16^{\circ}$ i $24^{\circ} \mathrm{N}$.

Największe skupiska $\underline{P}$. coupei występowały na głębokościach 30-150 m, głównie w rejonie Rio de Oro, Senegalu, Gwinei i Sierra Leone. Sredni stosunek średnicy oka i szerokości kości łzowej dodługości głowy był odmienny u osobników łowionych w rejonie Dakaru i Rio de Oro. Były to różnice statystycznie istotne. Połowy opierały się głównie na rybach z II, III i IV grupy wieku; średnia ich długość zwiększała się wraz ze wzrostem głębokości, wynosząc przeciętnie 19,3 cm. Współczynnnik śmiertelności całkowitej wynosił w rejonie Dakaru 1.58. Szybkość wzrostu osobników z rejonu Rio de Oro była wyższa niż w rejonie Dakaru. Analiza statystyczna wskazuje na istotność tej różnicy. Przyrosty ciężaru $P$. coupei zwiększają się do szóstego roku życia. Parametry równania v. Bertalanffy' ego dla rejonu Dakaru mają wartości: $\mathrm{L}_{\infty}=39,37 \mathrm{~cm} ; \mathrm{K}=0,18 ; \mathrm{t}_{\mathrm{o}}=-0,81$ roku, a dla rejonu Rio de Oro $\mathrm{L}_{\infty}=40,17 \mathrm{~cm} ; \mathrm{K}=0,19 ; \mathrm{t}_{\mathrm{o}}=-0,63 \mathrm{roku}$. $\mathrm{P}$. coupei jest obojnakiem. Obojnactwo to ma charakter protogynii. Rozród odbywa się w okresie od maja do września na rozległych tarliskach w płytkich rejonach przybrzeżnych. Podstawą pokarmu omawianego gatunku są Decapoda, Cephalopoda, Pisces, Amphioxus i Polychaeta - każdy z tych komponentów dominuje w innym okresie roku. W omawianym rejonie $\underline{P}$. coupei tworzy co najmniej dwa 
odrębne lokalne stada - Dakaru i Rio de Oro; trzecie takie stado występuje w rejonie Takoradi.

ПАГЕЛЬ ДЛИННОРЫЛЫЙ - PAGELLUS ACARNE (RISSO) ИЗ

PAVIOHA CEBEPO-ЗАПАДHOVI АФРИКИ

$P$ P $з$ ю $\mathrm{M}$

Работа посвящена исследованиям биологии сравнительно часто встречающегося в водах северо-западной Аб̆рики, но мало ещё изученного, вида - Раgeilus acarne (Risso). Материалы для исследований были взяты из уловов польских траулеров на шельфе северо-западной Афирики от $16^{\circ}$ до $24^{\circ}$ северной широты. Самые большие скопления этого вида встречаются мекду параллелями $19^{\circ}$ и $25^{\circ}$ северной широты на глубине 40 - 180 м. Отношение межглазничного пространства, диаметра глаза и ширины лакримальной кости н общеи длине было неодинаковым у.Р.acarne из. района Кап-Блан и у этого же вида из района Рио-де-0ро. Разница эта была статистинески. существенной. јоов Р.acarne основывается главным образом на III и IV возрастных группах. Средняя длина вылавливаемого Р.асате увеличивается вместе с глубиной и составляет чаще всето $21-26$ см. Коэф̆ф̆ициент общей смертности $(Z=F+M)$ состтавлял в районе Кап-Блан 1;05 (1969), и 0,781 (1970 г.), а в районе Рио-де-0ро - 1,27. Зависимость между общей длиной (і.t.) и длиной самого длинного луча отодита приближается к прямопропорциональной, что позволяет применять метод Дааль-Лея при.обратных вычислениях роста. Средняя длина в возрастных группах от I до VII составляет 13,7; 18,8; 21,$9 ; 24,6 ; 26,8 ; 30,5$ cм. Годово й прирост веса увеличивается доо седьмого тода жизни. Параметры возрастного уравнения фоон Берталаф̆б̆ составляют $; \mathrm{L}_{\infty}=36 ; 0 \mathrm{~cm} ; \mathrm{K}=0,23 ; \mathrm{t}_{0}=-0,97$ года. Р.acarne. является гермафродитом, гермафородитизм его отнояится к типу протандри. Изменение пола, т.е. переход из самца в самку, в районе Рио-де-Оро наблюдается у рыб менғшей длины, чем в районе Кап-Блан. Разможение происходит зимой. Нерестили. ща обширны, расположены в мелкцх прибрежных водах. Нерест является порционным. Основным нормом Р.асагnе являются Decapoda и Pisces; дополнительным - Ophiuroidea и Polychaeta. В paccматриваемом районе P.acarne образует по крайней мере два отдельных местных стада (Кап-Блан и Рио-де-Оро), отличащиеся друг от друга морфологическими признаками, упитанностью и скоростью роста.

Address :

Received 11.IX.1971

Dr Andrzej Kompowski Instytut Ichtiologii AR

Szczecin,ul. Kazimierza Królewicza 4 Polska - Poland 